\title{
1. Federalism and the engine room of prosperity ${ }^{1}$
}

\author{
The Hon Wayne Swan MP, Treasurer of Australia
}

Australian legal scholar Professor Greg Craven once described federalism as the topic most likely to clear an Australian barbecue. In the past 50 years, he wrote, 'Australian federalism has received more bad press than morbid obesity'. Whether you agree or disagree with Craven's views on federalism itself, it is hard to argue with his description of it as our own constitutional ' $\mathrm{F}$ ' word.

To most Australians, federalism is probably about as popular as a politician appearing onstage at a grand final. Yet while it might not so far have become the lead topic of conversation in the nation's lounge rooms and pubs, Australians do care about making public services work better. And in a system such as ours, it's hard to get better outcomes in areas such as housing, health and Indigenous affairs unless all governments work together.

I want to say something about the ambitious reforms we're implementing through the Council of Australian Governments (COAG), to offer a sense of the new architecture we propose and why it represents a fundamental improvement over the way we've done things in the past. Reforming the architecture of Commonwealth-state relations can sound a little airy, so I also want to provide a practical example of how our new approach will affect the lives of Australians. I want to describe what we're doing with school reform and how it exemplifies what we can achieve from modern federalism. There's no better reason to get federalism right than the opportunity it provides to improve our schools.

My whole political life I have believed education is the engine room of prosperity and the key to overcoming social disadvantage. It's why I devoted a big chunk of 2005 to writing Postcode: The splintering of a nation, my book on social disadvantage in Australia. Creating prosperity and spreading opportunity are why I entered politics. Education is what brings these two objectives together. I am relishing the opportunity we've been given to modernise the federation, so we can build a platform from which to reform Australia's education system.

As the government goes about lifting national productivity and creating a more inclusive society, Commonwealth-state relations and education reform is the place where Julia Gillard's policy agendas and mine frequently meet. Education reform - especially school reform - has been proposed in this country for a decade. Half-hearted attempts have been made, but they have not been backed up with the leadership and conviction needed to deliver structural change. Our predecessors never succeeded in navigating Australia's future - and there is no 
better example of this than the former treasurer's failure to invest in the education of our children.

In a number of developed countries, imaginative public policies have substantially improved the quality of school education and student outcomes. Greater transparency, along with new investment and greater flexibility, has been key to these improvements. By comparison, Australia's reform effort has been lacklustre. And one of the key reasons why is they have foundered on the rock of unreformed federalism. It's only now that we are creating a more flexible, market-driven set of Commonwealth-state relations that substantial education reforms can finally be realised. Ultimately, this is a major structural difference between the Rudd Government's school reforms and those that have been floated before them - not only because we have the will to revolutionise Australia's education system, but because we are modernising the federal structures to enable necessary education reforms and investments to be made.

\section{Modern federalism}

Every economy in the world today is facing tough economic conditions. The global credit crunch and global oil price shock have buffeted confidence and share markets and are slowing global growth. But as the National Accounts for the September Quarter 2008 demonstrated, while Australia is not immune, we are well placed in comparison with a number of other developed economies. And the Rudd Government is determined to press home this advantage. This means undertaking serious microeconomic reform - to boost our productivity, lift our international competitiveness and invest in our human capital.

In many respects, the COAG reforms are the centrepiece of the government's microeconomic reform agenda. The reforms are focused on what economists call 'enhancing public sector productivity' — or what just about everyone else simply calls 'better public services'. The changes in the financial relationship between the Commonwealth and the states that we are putting in place represent a major revamp of Australian federalism. The old ways of doing things have obviously not worked.

For decades, the Commonwealth imposed input controls on Commonwealth funding to the states - tough conditions to dictate the way funding was to be used. These conditions constrained flexibility and innovation in service delivery. This made it difficult for the states to set their own priorities. It also created inefficiencies, as the Commonwealth devoted unnecessary time to administering them. Most importantly, Commonwealth intervention in areas of state responsibility blurred the lines of accountability. The conditions imposed on Commonwealth funding confused the public because it was no longer clear whether the states or the Commonwealth was accountable for poor service delivery, or indeed good service delivery. If you doubt this, I suggest you go 
to a suburban shopping centre and ask the shoppers which level of government is responsible for improving their child's school.

This lack of public accountability is the reason COAG meetings became a routine blame game, with both levels of government blaming the other for poor service delivery and trying to shift expenditure responsibility. Voters were left unsure who was ultimately at fault, but quite sure that they wouldn't tolerate that kind of squabbling from their children. Old-style federalism was conducive to short-term fixes and political machinations - but it stood fundamentally at odds with delivering high-quality services and the necessary reforms to underpin future economic prosperity. We are committed to leaving it permanently in our wake.

There's been a lot written and a lot said about the future of federalism if the Carpenter Government is not returned in Western Australia. ${ }^{2}$ This misses the point. We've always said that we want to build a modern federalism that looks beyond current governments. The reforms we envisage are too important to be caught up in partisan politics. In education, for example, the future of our kids is far more important than any party political differences we have. That is why I am proud of the new financial framework that Australian treasurers have hammered out this year.

\section{New financial framework reforms}

In modernising Commonwealth-state financial relations in Australia, we have been guided by some commonsense principles. The states have a wealth of experience in how best to deliver services in their jurisdictions. The Commonwealth should leave them the scope to innovate and tailor solutions in a way that best fits the needs of their populations. This is not to say that there is no role for policy leadership by the Commonwealth. Many of the big challenges facing the economy are issues that need to be addressed through the Commonwealth working in partnership with the states.

So what do the new financial framework reforms mean in practice? The Commonwealth will continue to assist the states in their endeavours, but the states will be responsible and accountable. The new framework for federal financial relations will help to make that clear. That clarity in accountability will be achieved in several ways. First, the number of Specific Purpose Payments will be reduced from more than 90 to just a handful - in the areas of health care, early years education and schools, vocational education, disabilities and housing. To see what a fundamental break this is with the past, you have to recall that the number of Specific Purpose Payments has sat at about 100 for decades now. In this sense, our approach is radically different from what has gone before. This rationalisation will reduce wastage at a time when we can no longer sustain the excesses of the past. 
Second, the Commonwealth will give the states the budget flexibility they need to allocate resources where they will produce the best results. The Commonwealth will move away from the prescription of the past and remove the input controls that inhibit state service delivery and priority setting. Instead, the focus will be on the achievement of outcomes.

Third, the Commonwealth will provide the states with more funding certainty. States will be better off financially and will no longer be plagued with the uncertainty of not knowing whether they will receive Commonwealth payments. There will be no more five-year agreements with 'take it or leave it' offers when they expire. Instead, the new National Specific Purpose Payments will be ongoing agreements, reviewed periodically to ensure the maintenance of funding adequacy.

Fourth, and central to the new framework, there will be simpler, standardised and more transparent public performance reporting. The new reporting framework will focus on the achievement of results, value for money and timely provision of publicly available and comparable performance information. Roles and responsibilities will be clarified and the performance of each jurisdiction will be independently assessed by the COAG Reform Council.

Also central to the new financial framework reforms will be additional incentive payments to drive key economic and social reforms. National Partnership Payments will reward those states that best deliver the services and outcomes to their citizens, and not reward those that don't. In so doing, they will drive a new microeconomic reform agenda in this country. Most importantly of all, they will improve the quality of services available to the Australian people-including schools.

\section{Schools reform}

Australia has not traditionally been a highly educated country. It is easy to forget that in 1983, when the Hawke Government came to power, only four in 10 Australian children finished year 12. When Labor left office in 1996, that number had risen to seven in 10. Since then, there has been relatively little change in school completion rates. Higher educational attainment has a substantial productivity pay-off. On average, each additional year of education raises earnings by 10 per cent.

Education is particularly important at a time when developed-country labour markets are in a state of flux. Manual low-skilled jobs are increasingly disappearing, while employment growth has been concentrated in jobs requiring abstract cognitive skills, complex communication and exercising judgment in the face of uncertainty. Of course, manual jobs will not disappear, but there is also a trend towards higher skill requirements within occupations. 
As a recent Organisation for Economic Cooperation and Development (OECD) working paper pointed out, 'a bank teller today spends more time than in the past selling financial services, and less time performing routine tasks such as processing deposits and withdrawals. Similarly a mechanic can no longer function without the ability to read and to work with computerised testing equipment. ${ }^{3}$ What is driving these changes? One factor is the rapid advance of technology.

In a new book, Harvard economists Claudia Goldin and Larry Katz refer to the 'race' between education and technology. ${ }^{4}$ At times when technology outstrips education, inequality rises. Conversely, when education increases faster than technology, inequality falls. The other factor is globalisation. In the past few decades, India has opened its economy to the world, China has shifted to market capitalism and the former Soviet empire has collapsed. Another Harvard economist, Richard Freeman, vividly refers to these events as equivalent to another 1.5 billion unskilled workers joining the global economy. ${ }^{5}$

On balance, the expansion of the global economy has benefited Australians. But as immigration, trade and offshoring have expanded, many Australian workers suddenly find themselves in a global labour market. These findings have profound implications for anyone who cares about the most disadvantaged in our society. Although technological advances and globalisation are major contributors to rising living standards in Australia, they do not lift all boats equally. Public policy needs to recognise this and ensure that the gains from technology, trade and immigration are shared across society. Central to this is raising the quantity and quality of education.

It isn't easy to predict the occupational mix of the Australian labour market in the future. But it's a fair bet that one of the best things we can give to a young Australian today is a broad-based education - the foundation for lifelong learning. This will benefit the individuals themselves, but it will also have positive spill-overs. Better-educated adults pay more tax, are less reliant on income support and are less likely to commit crimes.

A comprehensive discussion of the government's schools reforms would take much longer than I have available to me here. So let me simply focus on two aspects of our reforms, which are symbolic of what we are working towards. These are transparency in school reporting and improving schools in low socioeconomic status communities.

\section{Transparency in school reporting}

In the private sector, it has long been recognised that information is central to well-functioning markets. It turns out that the same is true in the public sector. Giving people information about the performance of public services empowers them to spur reform. It is also consistent with this government's belief in transparency. We are ultimately accountable to voters, whose taxes fund 
government services. Those voters have a right to know how well these services are performing.

I've talked previously about the importance of reporting health outcomes at a hospital level — an agenda that Health Minister, Nicola Roxon, has been vigorously promoting. In this essay, I want to speak about a parallel agenda: reporting test score results at a school level.

During the past month, the Prime Minister and Deputy Prime Minister have made clear that we are committed to reporting test scores at a school level. This has not been uncontroversial, with some critics referring to it as 'unreliable and misleading', a 'divisive sideshow' and suggesting that we are engaging in 'bullying tactics'.

It is important that we engage with our critics on this issue. For the most part, they care about the same things that we do: ensuring that our education system is as good as it can be and that it particularly serves the needs of the most needy students. You cannot be serious about equality of opportunity unless you are committed to improving the quality of schools in disadvantaged communities. In achieving this goal, it is critical that we measure the performance of schools, so we can learn from the best and identify problems early.

But measuring school performance is not as simple as comparing their raw scores. In part, the differences between schools are due to their socioeconomic mix. We should not blame a school because it enrols children from low-income households or shower it with plaudits because it admits only the more affluent. That is why this government is committed to 'like school' reporting.

Separating what students bring to the classroom on day one from the value added by the school is not trivial - but it is not impossible either. Indeed, the challenge is similar to the one we face in separating hospital performance from case-load mix. We need to take account of whether one hospital treats sicker patients than another in determining hospital effectiveness.

A student's family background is an important influence on his or her success at school. But it would be a mistake to think that is all that matters. There are persistent and systematic differences between schools and we owe it to Australia's children to learn as much as we can about why one school does better than another. It is also important to remember that we are requiring all schools to be accountable - government and non-government.

For the first time in the nation's history, parents will be able to compare the performance of schools across Australia, taking into account the mix of students at those schools. If one school is performing far better than its socioeconomic mix would predict, why don't we see what we can learn from it? Sometimes the answer will be something that is hard to replicate - a charismatic principal, 
perhaps. But other times, we might find that schools can learn lessons from one another that can raise the performance of all.

In theory, information should matter - and in practice, we have good evidence that it does. Looking at accountability across all 50 states of the United States, Stanford academics Martin Carnoy and Susanna Loeb found that the largest test score gains were experienced in those states that published school-level results. White, black and Hispanic students all did better when schools in their state became more accountable. A strong and transparent accountability framework is a non-negotiable part of the COAG schools reform agenda, which reaches further and deeper than anything Australia has seen in the past decade and more.

For too long, public policy in this area has been made with an eye to short-term politics, not long-term improvements in policy outcomes. That's not the way this government does business. We believe that parents and the community have a right to know how their schools are performing and to compare them with other schools that serve similar populations.

\section{Schools in low socioeconomic status communities}

While greater transparency is necessary for improving underachieving schools, it's not sufficient. The government has therefore set out to provide new resources to schools in low socioeconomic status communities in order to spur reform in those schools. In my book Postcode, I described a quality education as 'a one-way ticket out of poverty'. But at the time of writing-2005-I also noted that 'education policies seem to be designed with the purpose of making it harder for students from poorer communities to compete with their wealthier peers'. According to OECD research, students in the lowest socioeconomic quartile lag behind those in the highest socioeconomic quartile by 2.5 years. It's time to change that.

Through the COAG process, we're aiming to help improve schools in low socioeconomic status communities. This involves targeting additional resources - about $\$ 500000$ per annum for a typical sized school - to the schools that serve the most disadvantaged children in Australia. Making these schools work better will raise gross domestic product (GDP) in the long run, but it's about more than that. We want poor children in Australia to enjoy an education as good - or better - than anyone else.

Our low socioeconomic status school reforms are about more than money. In aggregate, there is very little evidence to show that spending more money alone will result in better education performance. ${ }^{6}$ So we are committed to ensuring that this new spending spurs fundamental changes in these schools.

Over time, we hope that many of these reforms will be adopted in other schools. But we are starting at the place we believe is most important: the neediest 
neighbourhoods of Australia. Our reforms will provide more funding and greater discretion to principals and local school communities. They will help schools attract high-performing teachers and principals, and reward them for success.

Teaching in a disadvantaged area is one of the most important jobs in the nation. We need to ensure that more talented young Australians choose teaching in the future, and create incentives for them to work in the nation's neediest schools.

Through our low socioeconomic status reforms, schools will also have the flexibility to help students through after-school study support, new sporting programs, strong networks with the local community and links with local businesses. Private schools in leafy suburbs have long offered programs such as these to their students. But in low socioeconomic status communities, they have been the exception rather than the norm. With these extra resources, we also expect greater accountability.

We do not apologise for insisting that high standards should apply in every community. These proposed reforms have been criticised from some quarters as anti-teacher and even anti-public education. The opposite, in fact, is true. They are motivated by a passionate belief in the importance of good public schools and good teachers - a belief founded in personal experience, shared with the Prime Minister, during our years at Nambour High School.

Under these policies, school funding will follow need and be used to raise the quality, standing and remuneration of the teaching profession. And given the predominance of public schools in the ranks of disadvantage, this means the policies represent a new future for public education and for the teaching profession.

In many cases, there are excellent, dedicated principals and teachers doing a great job in these communities. Our task is to recognise those professionals and strengthen their efforts. Our policies are a lifeline for these teachers, should they choose to grasp it. I suspect the overwhelming majority of parents are hoping they will.

The reforms have also been dismissed as a copy of the previous government's policy. That too is wrong. The policies of the Howard Government set out to create something completely different: a set of 'dumb' league tables that offered no analysis of why some schools were underperforming and no strategy for addressing their underperformance. In contrast, our 'like schools' approach takes account of differences in family backgrounds across schools. And where we identify underperformance, we'll be in there doing our utmost to make sure those schools fulfil their potential. 


\section{Conclusion}

I've aimed to give you a flavour of what we are doing to modernise Commonwealth-state relations - and to give you two examples of the types of reforms we will be able to deliver, building on this new federal platform. My examples have focused on school reform because it brings together two of my longstanding policy interests. Education is both economic policy and social policy. It is now the key policy area where good economics and good moral values combine to produce the best results. This is the reason why social democratic parties around the world run for office promising their three top priorities will be 'education, education and education'. In a world of technological change and globalisation, we owe it to the next generation of Australians to provide the best possible education. This matters for all children-but it matters especially for the most disadvantaged.

For Labor, better schools are the cornerstone of a decent society. Indeed, quality schools might well be the best anti-poverty program available. Education increases productivity and participation, it builds prosperity and it also offers the hope of breaking the intergenerational cycle of poverty.

Modern federalism will enable us to finally undertake bold reforms to Australia's school system - notwithstanding the fact that the responsibility for schools policy in this country straddles Commonwealth-state boundaries. Our modernisation of the federation is driven by the same practical spirit that inspired Federation itself: a desire to create systems that stand the best chance of delivering for the Australian people.

We want to encourage innovation and problem solving at the local level-providing states with greater budgetary flexibility in return for greater transparency and accountability. And we are committed to major reforms to make public services work better, which we are backing with substantial new funding. Underpinning what we are doing is what I have called 'the Australian way'. The Australian way is the idea that we are all richer when we are able to participate in the economy, that inequality is bad economics and that better education is vital to creating a better society.

For me, these are moral certainties and they inspire the reforms that we are undertaking today.

\section{ENDNOTES}

1 This essay was originally presented as a keynote address at the ANZSOG Annual Conference on 11 September 2008.

2 The Labor Government of Alan Carpenter was narrowly defeated in the Western Australia state election on 6 September 2008.

3 Brook, Anne-Marie 2008, Raising education achievement and breaking the cycle of inequality in the United Kingdom, Economics Department Working Papers No. 663, Organisation for Economic Cooperation and Development, Paris. 
4 Goldin, Claudia and Katz, Lawrence 2008, The Race Between Education and Technology, Harvard University Press, Cambridge, Mass.

5 Freeman, Richard 2005, 'What really ails Europe (and America): the doubling of the global workforce', The Globalist, 3 June 2005.

6 See 2008-09 Budget Statement, vol. 4, pp. 4.24-25. 